Vanja Petrović

Univerzitet u Primorskoj

Fakultet za humanističke studije

Kopar, Slovenija

vanjapetrovic444@gmail.com
DOI: https://doi.org/10.18485/slovenika.2021.7.1.1

UDK: 821.163.4.09-93-31 Север C.

Darko Ilin

Univerzitet u Novoj Gorici

Fakultet za humanistiku

Slovenija

darko.ilin@yandex.com

\title{
Socrealistička poetika u romanima Sonje Sever za decu i omladinu objavljenim na srpskohrvatskom jeziku
}

\section{Sažetak}

Ovaj rad ima za cilj da sagleda Sonju Sever u kontekstu pripadnosti slovenačkoj književnoj tradiciji, ali istovremeno i zajedničkom književnom sistemu socijalističke Jugoslavije. Posebna pažnja pri analizi dela ove autorke posvećena je i različitim aspektima socrealističke poetike, koja predstavlja dominantan diskurs u proznom opusu Sonje Sever za decu i omladinu na srpskohrvatskom jeziku. U ovom radu, na primerima romana Mali Kinez Kong i Majko, zašto? pokazuje se na koji način je socrealistička poetika uticala na kompoziciju dela, oblikovanje likova i ideologizovanje pogleda na svet. Fokus naučnog istraživanja usmeren je i na načine na koje autorka uspeva da prevaziđe uske okvire i matrice ove stilske formacije, ukrsti je sa specifičnim zahtevima i funkcijama književnosti za decu i omladinu, te ostvari po mnogo čemu umetnički uspela dela.

Ključne reči: Sonja Sever, socrealizam, književnost za decu i omladinu, ideologija

\section{Sonja Sever u kontekstu jugoslovenskog književnog sistema}

Sonja Sever, rođ. Kamplet (1900-1995) bila je autorka književnosti za decu i omladinu, prevoditeljka i pedagoškinja, čije ime je zabeleženo samo na marginama jugoslovenske kulture. S obzirom 
na to da je skoro čitav svoj život delovala kako u Sloveniji, tako i u Hrvatskoj, postoje određeni problemi pri umeštanju ove autorke $u$ čvrsto postavljene okvire jedne nacionalne književnosti. Tako Zlata Pirnat-Konjar, istoričarka jugoslovenske književnosti za decu i omladinu, zapisuje da je Sonja Sever po rodu Slovenka, da je istovremeno hrvatska i slovenačka spisateljica, te njeno stvaralaštvo razdvaja na dva vremenska i nacionalna delokruga: slovenački predratni i hrvatski posleratni (Pirnat-Cognart 1980, 244). U skladu sa tim, moguće je o Sonji Sever promišljati u dva pravca: prvi bi pratio mogućnost da se autorka označi kao jugoslovenska, imajući u vidu da se njen aktivni stvaralački period poklapa sa trajanjem zajedničke države jugoslovenskih naroda. Druga mogućnost bila bi sagledati Sonju Sever u kontekstu misli Zvonka Kovača o piscima „dvojne pripadnosti“" (Kovač 2010). Tako se o njoj može razmišljati na sličan način kao i o Ivi Andriću, Vladanu Desnici, Josipu Ostiju, te Zofki Kveder, koja je, poput Sonje Sever, bila „i sama slovensko-hrvatski bastard, međukulturna spisateljica“ (Kovač 2016, 17).

U slovenačkoj istoriji književnosti određena pažnja se poslednjih godina posvetila prvoj fazi stvaralaštva Sonje Sever, i to njenim dometima na području pisanja bajki, u kojima se primećuje odraz slovenske i slovenačke tradicije, očuvanje patrijarhalnog poretka i receptivnost za orijentalne uticaje (Mihurko Poniž 2019). Međutim, korpus dela Sonje Sever koji postoji samo na srpskohrvatskom jeziku gotovo sasvim je ostao izvan granica naučne pažnje, možda upravo zbog autorkine dvojne pripadnosti. Stvaralaštvo autora ili autorke dvojne pripadnosti predstavlja metodološki problem kakav je moguće rešiti samo putem ,interkulturnog proučavanja južnoslovenskih književnosti“" (Kovač 2016, 61). Naime, zbog specifičnog kulturnog položaja svake od nacionalnih književnih i kulturnih tradicija unutar sistema jugoslovenske kulture, proučavanje pisaca koji su tokom svog stvaralačkog puta umnogome zamagljivali granice nacionalnih tradicija iziskuje drugačija metodološka rešenja. Ona će istovremeno poštovati tradicijske kontekste kako pojedinačne nacionalne književne tradicije, tako i kulturnog projekta jugoslovenske književnosti, kojoj posleratno delo Sonje Sever napisano na srpskohrvatskom jeziku neminovno pripada. Pod specifičnim kontekstom podrazumeva se i ideološki imperativ socijalističke književnosti, koji je u godinama neposredno nakon Drugog svetskog rata diktirao kulturnu i književnu politiku. Kao dela Sonje Sever koja nesumnjivo predstavljaju izdanke takve tradicije na srpskohrvatskom jeziku izdvajaju se roman Majko, zašto? i pripovedački ciklus Legende s Primorja, koji su objavljeni u istoj knjizi (1947), zatim roman Mali 
Kinez Kong, koji je objavljen zajedno sa pripovetkom Crveni lampion (1948), pionirska drama Novi život (1951), te pripovetka U bolji svet (1956), objavljena u okviru zbirke Darovi djetinjstvu, koju čine izabrane pesme i pripovetke autora književnosti za decu i omladinu koji su delovali u Hrvatskoj.

Kako je „[k]ulturni obrazac u Jugoslaviji nužno [...] morao imati predznak jugoslovenski i socrealistički“ (Pijanović 2012, 36), za promatranje poetskih osobenosti ove autorke od odsudnog je značaja skicirati socrealističku paradigmu u književnosti za decu i omladinu toga perioda, kako $\mathrm{u}$ južnoslovenskom, tako i u međunarodnom kontekstu. Za normativnu poetiku ove stilske formacije, pored karakteristika poput (načelne) usmerenosti ka istinitosti i korektnosti u prikazivanju stvarnosti, kao i crno-bele tehnike u karakterizaciji likova (modeli tipičnih pozitivnih i negativnih junaka) (Flaker 1985, 742-743), možemo izdvojiti i određene preporuke/ograničenja kada je reč o idejnim i tematskim tekstualnim kompleksima. Za to nam kao najparadigmatičniji primer, koji umnogome sažima osnovni duh socrealističke poetike, može poslužiti tekst Maksima Gorkog $O$ temama dečje književnosti:

Uopšte, potrebno je svu literaturu za decu stvarati na potpuno novom principu, koji otkriva široke perspektive naučnoumetničkom mišljenju. Ovaj princip može se formulisati ovako: u ljudskom društvu razbuktava se borba za oslobođenje radne energije radnih masa ispod pritiska svojine, ispod vlasti kapitalista, borba za novo ovaploćenje fizičke energije ljudi u energiju razuma [...] borba za vlast nad prirodnim silama, za zdravlje i dug život radnog čovečanstva, za njegovo svetsko jedinstvo i za slobodno, višestruko, bezgranično razviće njegovih sposobnosti i talenta. Eto, taj princip treba da bude osnov celokupne literature za decu i svake knjige uopšte, počev od knjiga za najmlađe $(1945,22)$.

$\mathrm{S}$ tim u vezi indikativno je istaći i dvostrukost upliva ideoloških doktrina kao dominantu stvaralačkog postupka. ${ }^{1} \mathrm{~S}$ jedne strane, strogo definisani okviri totalitarnog režima i političke podobnosti odneli su prevagu nad estetskim komponentama umetničkih dela, pa većina istoričara književnosti ovaj period posmatra u okviru skromnih poetičkih dometa ili, još radikalnije, kao period koji treba što pre preskočiti i zaboraviti (v. Majhut i Lovrić Kralj 2017, 60). S druge strane:

\footnotetext{
${ }^{1}$ O vidovima ideološkog diskursa u književnosti za decu više videti u: Opačić 2017 , 117-128.
} 
Paradoksalno, i pored svega ovoga, doba socijalističke Jugoslavije jeste i period u kojem se poklanjala velika pažnja književnosti za decu - možemo slobodno reći da verovatno nikada pre toga nije bila posvećena veća pažnja brizi za to šta deca čitaju i kakve ideje usvajaju čitanjem. Svi oni koji su se bavili vaspitanjem mladih naraštaja bili su izuzetno svesni snage uticaja dečje štampe (i knjige uopšte) na izgradnju ličnosti mladih čitalaca. O tome svedoči osnivanje brojnih odbora / saveza (te njihovih saveta i komisija) zaduženih za najmlađu populaciju, pa i za njoj namenjeno izdavaštvo (Opačić 2013, 296).

Za predmet ovog rada od izuzetnog značaja je ukazati i na žanrovski sistem socrealističke književnosti, odnosno na položaj romana na samom vrhu žanrovske hijerarhijske lestvice: „U okviru socrealističkog književnog stvaralaštva posebna pažnja bila je obraćana romanu kao književnoj vrsti. Roman je od strane ideologa komunizma smatran vrhuncem mogućeg ideološkog uticanja na čitalačku publiku“ (Konstantinović 2006, 73). Razlog za to možemo tražiti u težnji ovog žanra ka „totalitetu stvarnosti“ (Lukacs 1990), što je potencijalno na najbolji način moglo obuhvatiti korenitu promenu u svim segmentima društva, koju su političari i ideolozi komunizma/ socijalizma zagovarali. U fokusu ovog rada biće upravo nedovoljno istraženi romaneskni opus Sonje Sever na srpskohrvatskom jeziku (romani Mali Kinez Kong i Majko, zašto?), odnosno pokušaj da se iz pomenutih dela izdvoje tipične socrealističke matrice, načini na koje su ideološke namene teksta oblikovale dela na različitim strukturnim nivoima, ali i da se ukaže na umetnički vredne segmente, koji, iako marginalizovani ili zatamnjeni zbog ideoloških matrica i kretanja književnog stvaralaštva u okvirima „kategorija progresivno i reakcionarno" (Opačić 2013, 297), ipak ova dela na izvestan način izdvajaju iz pamfletsko-propagandnog korpusa tekstova i čine podsticajnim za hermeneutička razmatranja.

\section{Laki odgovori na teška pitanja u romanu Majko, zašto?}

Korenite promene $\mathrm{u}$ jugoslovenskom kulturnom prostoru posle Drugog svetskog rata, a kao najveća od njih uspostavljanje socijalističkog društvenog sistema, uticale su na to da dečija književnost jugoslovenskih naroda unekoliko izmeni svoje obličje i usmeri se prema sve intenzivnijoj pedagoškoj i formativnoj funkciji, nauštrb estetske. Nova jugoslovenska dečija književnost nastojala je da na radikalan način raskrsti sa pređašnjom tradicijom, te je uporišta pronalazila u modelima i iskustvima koje je pružao Sovjetski Savez 
(Majhut i Lovrić Kralj 2017, 61). To početno razdoblje Mira Alečković određuje kao period popularisanja narodne revolucije i socijalističke izgradnje, te ističe da se u tom periodu može govoriti o dominaciji lirike, dužih narativnih pesama i kratkih pripovednih formi $(1955,365)$. Razlog za dominaciju poezije može se pronaći u tome što je u poetskom diskursu „lakše postići da riječi zazvuče poletnije, da riječi pokrenu na akciju, na juriš, da zvuče izazovnije“" (Majhut i Lovrić Kralj 2017, 67-68), dok su romani za decu iz pomenutog razdoblja značajno malobrojniji.

Centralna tema socrealističke književnosti u Jugoslaviji bila je Narodnooslobodilačka borba, koja združuje ratnu herojsku tematiku sa socijalističkom revolucijom, čineći je time veoma plodotvornim i korisnim oruđem za stvaranje i utvrđivanje nove kulturne klime. O književnosti s temom NOB-a najčešće se govori u kontekstu svedene i jednoznačne karakterizacije i polarizacije likova, međutim, takav pristup je razumljiv budući da je piscima književnosti za decu i omladinu „[b]lizina događaja i vremena o kojem su pisali bez neophodne distance nametnula [...] osoben tretman ratne građe“ (Idrizović 1976, 35). Status ratne tematike u dečijoj književnosti u neku ruku odudara od naivne slike sveta, tipične za ovaj narativni diskurs, i specifičnosti horizonta očekivanja, pa se postavlja pitanje da li postoji način prigodne reprezentacije ratnih zbivanja u književnosti za mlade čitaoce. Dubravka Zima primećuje da kako u diskursu književnosti za decu i omladinu, tako i u teorijskom govoru o njoj postoji snažna tabuizacija ratne tematike (2001, 83). Stoga, ukoliko se uzme u obzir da je književnost NOB-a u postsocijalističkom kontekstu skrajnuta, jugoslovenska dečija književnost s ovim tematskim okvirom predstavlja izrazito tabuizirano područje istorije književnosti.

Roman Majko, zašto? Sonje Sever objavljen je 1947. godine, a kako se navodi u impresumu, knjiga predstavlja prevod sa slovenačkog rukopisa. To pretpostavlja postojanje originalne verzije napisane na slovenačkom jeziku, međutim, takvo delo nikada nije izdato. Zlata Pirnat-Konjar ističe da je Sonja Sever jedna od retkih žena koja se tokom prvih godina nakon osolobođenja u svojoj dužoj prozi bavila ratnim temama (Pirnat-Cognart 1980, 245). Ovaj roman na prvi pogled predstavlja tipičan primer dečije književnosti NOB-a, zbog toga što kao centralnu temu uzima građu iz neposredne istorije NOB-a, koja ima dvostruku funkciju. Na prvom mestu, ovo delo predstavlja roman sa istorijskim elementima, ako se ima u vidu da se može razumeti kao delo koje obrađuje događaj iz istorije. Međutim, istorijske okolnosti NOB-a predstavljaju okosnicu za ra- 
zvoj središnje ideološke teze, koju roman nedvosmisleno posreduje čitaocu. Govoreći o mogućnostima narativizacije ratne tematike $u$ književnosti za decu, Dubravka Zima ističe da autori po pravilu biraju dve pripovedne instance, $i$ to jednu koja pokušava da pripoveda o ratu onako kako ga vidi dete, dok je druga „ona koja rat prikazuje onako kako ga odrasli djetetu pripovijedaju, tumače i opisuju (što uključuje ideologiziranost diskursa, shematičnost, dječje likove sa funkcijom) “ (2001, 84). U romanu Majko, zašto? može se primetiti preplitanje ovih dveju pripovednih instanci, koje zajedno tvore tipičan diskurs prve faze jugoslovenske socrealističke književnosti za decu i omladinu sa tematikom iz NOB-a.

Ovaj roman združuje dve pomenute pripovedne perspektive, gde čitalac ima priliku da prati dva toka priče, koji međusobno utiču jedan na drugi, izgrađujući time sliku ratnih dešavanja koja su prikazana kako iz vizure glavnog junaka (dečaka Metoda), tako i njegovog oca, majke i ostalih partizana iz sela. Ako se ima u vidu vreme kada je ovaj roman objavljen, tema NOB-a još uvek predstavlja događaj iz neposredne istorije, koji je imao sudbinsku važnost za konstruisanje ideološkog sistema socijalizma i izgradnju jugoslovenske države nakon Drugog svetskog rata. Stoga je autorima bilo važno da se u svojim delima za decu i omladinu osvrnu na značaj tog rata za savremenu Jugoslaviju, što je u periodu intenzivne primene socrealističke poetike predstavljalo poetički i tematski imperativ. Upravo zato je u romanu Majko, zašto? prisutno mnoštvo segmenata koji opisuju ratno stanje, skrivanje partizana u brdima iznad sela, planiranje odbrambenih strategija i slično. Ovi segmenti karakteristični su za književnost za odrasle, međutim, takvi motivi su prisutni u romanu iz potrebe da se mladim čitaocima predstavi jed(i)na moguća narativna reprezentacija tog odsudnog događaja.

Dubravka Zima kao jedan od mogućih modusa narativne organizacije ratne tematike u književnosti za decu navodi obradu rata kao sazrevanja: to je modus obrade „koji za svoju temu odabire užas i nesigurnost koju rat stvara u dječjim životima, izmještenost djeteta iz svakodnevice“ $(2001,85)$. Ovakav modus jeste dominantno organizaciono načelo romana Majko, zašto?, koje se može stoga razumeti i kao roman o sazrevanju dečaka Metoda. Međutim, ideološki elementi i premise socrealizma $u$ ovom romanu ostvarene su nauštrb psihološke uverljivosti likova i njihovog razvoja, te motivacije događaja, koja može u određenim segmentima delovati u nedovoljnoj meri opravdano. Tako možemo izdvojiti neke junake iz romana koji predstavljaju likove-funkcije. Siromašni i napušteni dečak Tomica poslužiće da u mladom Metodu izgradi svest o potlačenosti 
pojedinih društvenih klasa i nejednakosti među ljudima koja potiče iz kapitalističkog društvenog poretka: „Te večeri Metod dugo nije mogao zaspati. Gladni Tomica, i njegova siromašna sakata majka u općinskoj straćari, a s druge strane pune pekarne kruha i velike lijepe kuće u selu [...] zašto je bio Tomica gladan kad ima u pekarni toliko kruha? I zašto on mora sa materom da stanuje u prosjačkoj općinskoj straćari kraj tolikih kuća u selu?" (Sever 1947, 12-14). Tomičin lik služi za izgradnju klasne svesti kako kod Metoda, tako i kod idealnog čitaoca kakvog pretpostavlja poetika socrealističkog romana, dok lik dečaka Mike predstavlja njegov antipod, koji Metodov otac eksplicitno karakteriše rečima: „Mika je zao dječak“ (Sever 1947, 33). Ovakav vid karakterizacije predstavlja primer crno-belog oblikovanja likova u socrealističkoj književnosti, što umanjuje estetsku vrednost književnog teksta, sa druge strane ističući ideološku i vaspitnu funkciju dela, koje se bez poteškoća može čitati i kao priručnik za izgradnju poželjnog mladog predstavnika/mlade predstavnice socijalističkog društva.

$\mathrm{S}$ druge strane, $\mathrm{u}$ romanu se mogu pronaći i sadržinski elementi koji odudaraju od društvenih i kulturoloških pretpostavki socijalističke slike sveta. Na primer, u romanu Majko, zašto? mogu se primetiti ostaci religijskih elemenata u svakodnevnom životu. Likovi u romanu vreme mere prema hrišćanskim religioznim praznicima, te se kao temporalne oznake pominju Uskrs, Veliki petak, Cvetna nedelja i Božić. Ovakav modus poimanja vremena karakterističan je za narodni kalendar, koji u svojoj osnovi pak sadrži hrišćanski (crkveni) kalendar (Slovenska mitologija 2001, 256). Tako se u ovom romanu može govoriti o „izostanku komunističke rigidnosti“ (Majhut i Lovrić Kralj 2017,62) u nekim segmentima prvog razdoblja jugoslovenske socrealističke književnosti.

U romanu Sonje Sever prisutan je i motiv suzdržavanja od uzimanja hrane koju je potrebno sačuvati za druge partizane. Tako Metod, u stanju ekstremne gladi i iznurenosti, leži pored vreće sa hranom koju mora da sačuva za svoje drugove: „Ni sam nije znao kako se je to dogodilo, da mu se ruka našla na vreći i opipavala je [...] Zastidio se. Trgnuo je ruku od vreće i turio je duboko u džep. Pa ipak, bio je strašno gladan! Ne samo ruka, čitavo mu je biće težilo tamo prema vreći. Sve ga je vuklo tamo“"(Sever 1947, 93). Ovaj motiv može se dovesti u komparativnu vezu sa znamenitom kanonskom pripovetkom Kašika Antonija Isakovića, gde će pomenuti motiv dobiti posebno istaknutu notu tragizma. Na osnovu toga motiva, kao i mnogih drugih $\mathrm{u}$ ovom romanu (Metodovo samostalno delovanje i otpor protiv okupatora u selu, njegovo pridruživanje partizanskoj 
četi), može se govoriti o romanu o razvoju mladog partizana. Kako navode B. Majhut i S. Lovrić Kralj, u partizanskim romanima prisutan je lik deteta-heroja, koji se bori rame uz rame sa odraslima, najčešće preuzimajući uloge kurira, te je njihova dečija percepcija prilagođena percepciji odraslog, koju karakteriše prezir prema sadašnjosti i nedaćama u ime stvaranja komunističke budućnosti (2016, 45). Metodov lik se, posmatrano u tom kontekstu, sasvim uklapa u koncepciju deteta-heroja socrealističke proze za decu. Tako se pred čitaocima romana Majko, zašto? odvija narativizacija procesa razvijanja klasne svesti i postajanja detetom-herojem, što predstavlja temeljnu vaspitnu dimenziju ovog književnog dela.

$S$ druge strane, središnji motiv ovoga romana mogao bi se razumeti kao zapitanost nad strahotama rata, te nepravdama $\mathrm{u}$ društvu, što je u skladu i sa naslovom samog dela. Naime, motiv pitanja upućenog majci, te lajtmotiv „majko, zašto?“ u romanu se ponavlja više od dvadeset puta, čime se, s jedne strane, narativno simulira radoznalost deteta, dok se, $\mathrm{s}$ druge strane, ističe njegova nemogućnost da racionalno obuhvati ne samo ratne strahote već $i$ društvenu klimu, koja je dovela do rata, a naposletku i do socijalne revolucije. Lajtmotiv dostiže kulminaciju u poslednjem segmentu romana, kada u prelomnici boja Metod ostaje sasvim sam, bez nade u bilo kakav pozitivan ishod: „Sva ta pitanja, svi ti 'Zašto?' odjednom se pretvorili u oštre čelične ostruge. Vidio ih je, svijali su se kao zmije i u divljem plesu derali i rezali mozak i lubanju. A bilo ih je sve više i više. Uskoro nisu imali više ni mjesta za to svoje savijanje i previjanje... Jao, glavu će mi raznijeti! Hoće da izađu napolje u svijet..." (Sever 1947, 94). Ovakva izrazito ekspresivna i zlokobna, te gotovo avangardistička predstava junakovih misli unekoliko izlazi izvan okvira socrealističke poetike, čime Sonja Sever prevazilazi horizont očekivanja ne samo socrealizma već i književnosti za decu i omladinu, što predstavlja nesumnjivo umetnički vredan aspekat ovog romana.

Zaključni segment romana predstavlja majčin odgovor na brojna neodgovorena pitanja kroz fantazijsku viziju, koja istovremeno ima utopijski i antiutopijski karakter u kontekstu socijalističkog pogleda na svet: „Ušla je majka, sva u nekom divnom nadzemaljskom svijetlu. Nikada je još nije vidio tako lijepu. [...] Lice joj je bilo svježe, glatko, bez onih nabora, koje joj je zadnjih dana patnja bila po njemu zarezala" (Sever 1947, 95). Scena u kojoj majka na magičnom letećem ćilimu odvodi Metoda na putovanje oko sveta kroz konkretne geografske predele bogata je ideološkim implikacijama. Naime, ovo putovanje sastoji se iz prikaza klasnih razlika, buržoaskog i mo- 
narhističkog bogatstva u kontrastu sa bedom i nesrećom potlačenih slojeva, kolonijalnih i imperijalnih poduhvata, logoraša i prosjaka. Ovaj izrazito ideologizovani segment propraćen je implicitnim geografskim odrednicama poput negativno konotirane zemlje Kipa slobode i dolara, potlačenih afričkih zemalja i nepojmljivog raskoraka između vladara i naroda u zemlji maharadža. Pozitivno je konotirano jedino društveno uređenje Sojvetskog Saveza, koje predstavlja utopiju socijalističkog sveta:

Nepregledna zemlja bila je svuda jednako brižno obrađena najmodernijim strojevima. Narod je svuda radio složno i veselo. Nigdje se nije vidjelo nezaposlena čovjeka, nigde odrpanca, koji bi se sa prosjačkom palicom i ubogarskim prtom vukao prašnim cestama. [...] A gle, tamo u onoj drugoj dvorani igraju radnici šah i domino, i slušaju radio. O, kako su, majko, sretni radnici u toj zemlji! [...] Majko, gledaj, Staljin! Sam Staljin sjedi tamo za onim stolom i piše. Majko, ja ga dobro poznam. Otac mi je često pokazivao njegovu sliku i govorio: Zapamti, Metode, to je otac svih radnika na svijetu, dobri djed sve vrijedne djece, napose pak djece ubogih (Sever 1947, 115-117).

Naposletku se Metodovo putovanje okončava u rodnoj Sloveniji, u kojoj nailazi na sliku sebe iz budućnosti, koja predstavlja ostvarenje socijalističkih ideala za koje su brojni partizani položili svoje živote.

U čitavom romanu, a posebno u njegovom završnom fantazijskom segmentu, onoga što će se ispostaviti da je bio Metodov san, prisutni su eksplicitni ideološki elementi u skladu sa socijalističkim pogledom na svet. Takvo nedvosmisleno uključivanje ideoloških izjava predstavlja pokušaj ukidanja bahtinovske dijalogičnosti kao inherentne odlike romana, te nastoji da detetu-čitaocu nametne konstruisan unificiran monološki pogled na svet, koji ograničava dijaloški potencijal romana (McCallum 1999). Tako se isticanjem vaspitne i ideološke funkcije sputava mogućnost da čitaoci oblikuju sopstveno viđenje sveta, te se ovakav postupak graniči sa direktnom indoktrinacijom. Međutim, način na koji je izveden kraj ovoga romana na naročit način izlazi iz okvira socrealističke poetike i njenog imperativa u realističnosti prikazivanja. Zlata Pirnat-Konjar navodi da početak romana obećava i da je fabula dobro razvijena, ali da je kraj romana slabo izveden, isuviše sentimentalan i melodramatičan, te da je vizija komunističkog društva s kraja romana posve neuverljiva (Pirnat-Cognart 1980, 245). Iako se njena tvrdnja o neuverljivost može prihvatiti, važno je istaći da ovaj izlet u ideološki obojenu fan- 
tastiku predstavlja inovativan aspekat socrealističke književnosti za decu. Sonja Sever u ovome romanu istrajno i temeljno ostaje na tragu naslovnog motiva dečije zapitanosti nad strahotama rata, da bi kasnije tek u sferi fantastičnog uspela da dâ odgovor i time stvori jednu moguću narativnu konstrukciju traumatičnog događaja, a uz to jedan mogući modus prevazilaženja takve traume.

\section{Tajfun revolucije i vesnici slobode - poetika romana Mali Kinez Kong}

Kako navodi Urša Zidanski, Mali Kinez Kong prvobitno je napisan na slovenačkom jeziku (Mali Kitajec Kong), a za ovaj roman Sonja Sever je dobila prvu nagradu časopisa Naš rod 1941. godine. Štampan je na ćirilici u izdanju Prosvjete iz Zagreba 1948, a preveden je i na makedonski jezik (Малиот Кинез Конг) u izdanju Novog pokoljenja u Skoplju 1950. godine. Posebno interesantna činjenica koju autorka istraživanja ističe jeste i to da su izdavači smatrali da bi knjiga koja bi obuhvatala samo roman Mali Kinez Kong bila pretanka, pa je Sonja Sever dopisala još jednu priču sa sličnim tematskim okvirom, pod nazivom Crveni lampion (slov. Rdeči lampijon). Uz to, valjalo bi napomenuti da je Mali Kinez Kong u skraćenom obliku ušao i u čitanke za 5. razred iz 1953. godine $(2016,66-67)$, što svedoči o priznatosti ove autorke $\mathrm{u}$ datom kontekstu i vremenu.

Pre nego što se upustimo u analizu samog teksta romana Mali Kinez Kong, interesantno je ukratko se osvrnuti i na samo grafičko oblikovanje ove knjige. Pitanju značaja ilustracija u knjigama za decu, kao i analizi ondašnjeg materijala i izdavačkih praksi, koji su okvalifikovani kao neadekvatni i siromašni, pažnju su posvetili i ideolozi i umetnici socrealističkog kulturnog miljea, ističući vrednost „[...] emocionalno-uspelog crteža, koji bi nagonio mladog čitaoca da sa uzbuđenjem gleda na slikama poznate junake iz teksta" (Tauber $1945,40)$. Na tom tragu jeste i činjenica da „, [s]avremena tumačenja ilustraciju ne tretiraju više kao statično delo, već kao 'vizuelni' tekst“, koji kreira „nove modele čitanja i doživljaja ilustrovanog sadržaja" (Stevanović 2019, 73). Ovo stanovište od posebne je važnosti jer se imagološka predstava o stranoj i dalekoj kulturi, kakva je iz naše perspektive Kina, umnogome može kreirati upravo pomoću početnih vizuelnih stimulansa. Za ilustrovani materijal romana Mali Kinez Kong bio je zadužen Fedor Vaić (1910-1987), hrvatski grafičar koji je svojim „[s]enzibilnim i istančanim crtežom čistih kontinuiranih linija postizao u tušu različite tonske vrijednosti, os. u aktovima i animalističkim motivima $u$ kojima se jezgrovitošću prikaza pri- 
bližio klasičnim japanskim majstorima“ (Hrvatska enciklopedija). Iako u određenim segmentima odražavaju stereotipne predstave o Kini, ilustracije u ovom romanu možemo smatrati umetnički uspelim. One svojim detaljnim prikazom različitih pejzaža i kulturnih miljea, kao i različitih grupa likova, dodatno potcrtavaju umetnički vredne delove teksta, upotpunjujući recepciju dela i omogućavajući najmlađim čitaocima da prodube svoj doživljaj kulture koja im može biti daleka i nepoznata. ${ }^{2}$

Kada govorimo o kompoziciji ovog dela, primetna je linearnost i sukcesivnost u organizovanju narativnih celina, što na neki način i jeste svojstveno avanturističkim romanima, ali i revolucionarnom zamahu, u okviru kog nije moguće (ili pak nije poželjno) vraćanje na početnu tačku. Uz to, valja istaći i dvostrukost sižejnih tokova u kompozicionom organizovanju dela. $U$ fokusu pripovesti jeste sudbina malog Konga i njegova potraga za sestrom, koju su roditelji prodali kako bi isplatili pogreb preminulog člana porodice. ${ }^{3}$ Treba ipak imati u vidu da ovu sižejnu nit pre možemo razumeti kao pokretački impuls za Kongovo napuštanje rodnog mesta i avanture po svetu nego noseću kompozicionu strukturu delu. Razlog za ovakvo stanovište jeste činjenica da sestra, kako narativ odmiče, gubi sižejnu funkciju i prepušta je drugom, ideološki obojenom sižejnom kompleksu vezanom za potragu za kanarincem, koja se izjednačava sa začetkom revolucije i osvajanje slobode: „Sad razumijem, Kong, zašto si se dao na tako težak i dugi put. Tvoj kanarinac je zaista neobičan pjevač. [...] Njegova je pjesma lepa i radosna kao pjesma slobode; taj mali pjevač je vjesnik novog vremena i novoga života koji dolazi“" (Sever 1948, 97). Indikativno je naglasiti i kraj ove potrage, koja se pretvara u kolektivni trijumf, pošto kanarinci širom Kine počinju da uče pesmu slobode, a u tome ih podučava upravo Kongova ptičica. Ovu sižejnu liniju pre svega možemo razumeti kao svojevrsnu razvijenu alegoriju širenja revolucionarnog duha. Krećući od

\footnotetext{
${ }^{2}$ Roman Majko, zašto? takođe je opremljen ilustracijama partizanskog života i ratnih događanja, za koje je odgovoran Andrija Maurović, „stvaralac koji je svojim delom obeležio čitavu epohu jugoslovenskog stripa“ (Draginčić i Zupan 2005), što svedoči kako o značaju romana Sonje Sever u kontekstu socrealističke književnosti, tako i o značaju ilustracija kao vizuelnog stimulansa u recepciji ideološki obojenog književnog sadržaja.

${ }^{3}$ Na prvi pogled, ovakvo sižejno rešenje možemo smatrati umetnički neubedljivim, pogotovo ako imamo u vidu kontroverznost samog čina i potencijalna reakcija mladih čitalaca. Međutim, ako se u obzir uzme snaga kulta predaka u kineskoj kulturi (kako tradicionalnoj, tako i modernoj) (v. Addison 1924, 492-503) i moguće konsekvence nesahranjivanja određenog člana porodice, ovakvo rešenje na neki način može delovati kao autentična reprezentacija date kulture.
} 
konkretne stvari bliske dečijem iskustvu, a potom klizeći ka opštijoj ravni, najmlađoj publici predstavljaju se, u skladu sa njihovim horizontom razumevanja, mehanizami revolucije, odnosno ideja da oni skrajnuti, mali i siromašni mogu pokrenuti korenite promene $u$ društvu i svetu.

Kao važan element pri promatranju poetike ovog romana možemo izdvojiti i žanrovsku sinkretičnost. „Kada je reč o periodizaciji i klasifikaciji socrealističkog romana, u skladu sa ideološkim poimanjem vremena, moguća je podela socrealističkog romana na roman o predrevolucionarnom vremenu, roman o revoluciji i roman o poslerevolucionarnom vremenu" (Konstantinović 2006, 73-74). Na tragu te klasifikacije, roman Mali Kinez Kong mogli bismo svrstati u predrevolucionarno vreme i same začetke revolucionarnog. Međutim, pored navedene klasifikacije, treba napomenuti i to da se $u$ ovom romanu mogu pronaći rudimentarni oblici različitih romanesknih vrsta, poput avanturističkog romana, zatim bildungsromana, odnosno kunstlerromana (Kongove rezbarije i figurice oduševljavaju sve ljude) i romana s tezom. Iako je poslednja u nizu žanrovskih odrednica verovatno pretežnija od ostalih, ova žanrovska polimorfnost doprinosi naročitoj dinamici narativne strukture, fluktuirajući među opozicijama poput opšte : posebno, kolektivno : individualno, svoje : tuđe.

Odabir Kine za hronotop na neki način predstavlja hermeneutični ključ za razumevanje celokupnog dela. ${ }^{4} \mathrm{U}$ prezentovanju ove zemlje u romanu Mali Kinez Kong prisutan je svojevrsni paradoks. $S$ jedne strane, Kina se doživljava kao daleka i čudesna zemlja puna mitskih stvorenja, nalik na hronotope bajki ili legendi, uz određen broj karakterističnih/stereotipnih elemenata svojstvenih našoj percepciji Dalekog istoka:

- Don, din, don, din! - zvone zvonca sa visokih pagoda i svojim prodornim glasovima gone zle duhove, koji bi htjeli da strašnim olujnim vjetrom tajfunom daju smrt i razaranje među vrijednim kineskim ljudstvom. U velikim okruglim hramovima, bogato ukrašenim rezbarijama od skupocjena drva i slonove kosti, pjevaju kineski svećenici lame. Oni se duboko klanjaju pred golemim kipovima boga Bude, koji dostojanstveno sjede na svojim prijestoljima i sa smiješkom gledaju preda se; klanjaju se i pred sablasnim buljookim kipovima lavljih pandža i zmajevskih repova. Pjesma svećenika razliježe se i danju i noću kao šum rije-

\footnotetext{
${ }^{4}$ Za bolje razumevanje odnosa NR Kine i Jugoslavije $u$ ovom periodu više videti u: Arežina 2013, 35-54.
} 
ka, a pustinjski prah pada kao rodna rosa i pokriva zemlju i narod zlatno-žutim odbljescima.

U toj dalekoj čudnoj zemlji živeo je mali Kong (Sever 1948, 5).

Takođe, valja napomenuti da je izmeštanje radnje u daleku, polučudesnu zemlju moglo biti motivisano i potencijalnom zaštitom od eventualnog pogrešnog (političkog) tumačenja sadržaja, što je istovremeno $\mathrm{u}$ izvesnom smislu omogućavalo i relativnu slobodu umetničkog izražavanja bez bojazni da bi se izvesni sadržaji mogli pogrešno razumeti i sankcionisati.

Ona druga, čitaocima toga vremena bliska Kina ticala bi se društvenog uređenja i različitih antagonizmima među stanovnicima te zemlje. Kao i u velikom broju drugih socrealističkih tekstova, predstava o ovoj zemlji podređena je tipičnoj kritici kapitalizma:

Režim se trudio da neprestano ojačava samopredstavu građana o pravednosti društvenog ustrojstva. To je bilo najočiglednije pokazati crno-belim predstavljanjem sopstvenog i tuđeg uređenja. Slika o njima (kapitalistima) oblikovana je kao jasna antiteža nama i morala je da budi krajnju odbojnost u svesti čitalaca. Taj odijum izgrađivan je naglašavanjem njihove neljudske prirode (često im se u prikazivanju pridodaju aluzije na demonska bića iz bajki): oni su gramzivi, pohlepni, zlostavljaju siromašne radnike [...] (Opačić 2013, 299).

Upravo iz navedenih razloga, opozicija bogatih i siromašnih jedna je od dominanti idejnog sloja dela, ali i dinamički motiv koji pokreće radnju (prodaja sestre usled nemogućnosti da se isplati pogreb za dedu i sl.). „Jedna od osnovnih karakteristika romana u funkciji pripreme revolucionarnog prevrata je ta da su socrealistički pisci kao ciljane grupe odredili najsiromašnije slojeve stanovništva, nacionalno marginalizovane društvene grupe, kao i žene“ (Konstantinović 2007,168 ). S tim u vezi možemo istaći i da modelovanje i karakterizacija likova predstavljaju umetnički možda najslabiju tačku ovog romana. Gotovo kao u bajci, svi likovi svedeni su isključivo na sižejne uloge koje im se dodeljuju, ili pak na funkcije određene socijalističkim pogledom na svet (primera radi, sveštenici su, u skladu sa vladajućom ideologijom, karakterisani kao prevaranti koji koriste praznoverja kako bi zaradili novac). Čak ni glavni lik romana nije značajnije psihološki nijansiran - njegova uloga više je kohezivna u smislu povezivanja različitih narativnih tokova nego što je u pitanju ubedljiv i mladim čitaocima prijemčiv književni lik. 
Zanimljivo je istaći kako se motiv siromaštva u ovom delu opet povezuje sa motivom tajfuna, uz ekspresivne slike koje dočaravaju dramatičnost i očaj stanovnika plovećeg grada:

Ali još gori dani nastali bi za stanovnike plovećeg grada kad bi iznenada zahujao vihor i more počelo bjelasati. Kao poplašeni pilići, kada među njih sleti jastreb, raspršili bi se čamci i pohitali u pristaništa obližnje luke da se zaštite od bijesnih valova. Gotovo nikada se nije dešavalo da se svi spase. [...] Ali čim bi zasjalo sunce, a more se stišalo i opet pružalo kao ravno ogledalo, uskoro bi se sakupili natkriveni čamci na svom starom mjestu kraj ušća Svete Rijeke, i na otvorenom moru opet bi se njihao ploveći grad. Tu bi ljudi živjeli kao i prije, i niko ne bi tugovao za onima koji su našli smrt u bijesnim valovima. A čemu i da tuguju? [...] Ta, znalci i prijatelji, koji su nestali, otišli su u neki drugi, daleki svijet, gde nema patnje i muka kao tu, u tom plovećem gradu. Tako su mudrovali ubogi Kinezi (Sever 1948, 6-7).

Na ovom mestu ukazali bismo i na deskriptivnu virtuoznost ove autorke, što je segment $\mathrm{u}$ kom najpre treba tražiti umetničke kvalitete ovog teksta. Uz to, kao poseban estetski kvalitet treba istaći i brižljivu kompoziciju dela, odnosno korišćenje dozivajućih motiva, koji će svoju realizaciju i metamorfozu dobiti u daljem toku narativa. Motiv vetra na svojevrstan način predstavlja temeljno kompoziciono ustrojstvo jer na različite načine spaja višestruke tematsko-motivske komplekse, sižejne tokove i uokviruje samo delo. Semantička pregnantost ovog motiva dodatno se potcrtava njegovim pojavljivanjem na obode teksta, čime dobija istaknuto strukturnu mesto $\mathrm{u}$ kompoziciji dela (v. Uspenski 1979). Na početku romana motiv vetra povezan je sa načelom destrukcije, smrti i siromaštva. Međutim, tokom narativa on se preobražava u svojevrsno revolucionarno načelo, koje donosi korenite promene i slobodu svim narodima sveta:

- Djeco, zaista se rodila nova pjesma slobode i bratstva, pođi-

te i nosite tu pjesmu buđenja $u$ narod da zazvoni u svim srcima! O dođi, vjetre iz gaja, pa i ti ponesi pjesmu širom naše zemlje, ponesi je preko gora i mora da je upoznaju narodi čitave zemlji i da izgrade novi, bolji život (Sever 1948, 108).

Indikativno je u ovom odlomku primetiti i apostrofu koja obuhvata i samog recipijenta, pa se zapravo, po (fiktivnom) kineskom modelu, ljudi svih zemalja pozivaju da učestvuju u izgradnji boljeg (u ovom slučaju socijalističkog) društva. Kraj dela, na taj način, prelazi granicu fiktivnog i preliva se u realnost, što možemo smatrati vidom naročitog književnog angažmana. Ukoliko se razume van 
konteksta socrealizma, poruka s kraja romana može se protumačiti i kao umetnički uspela, jer u izvesnom smislu ima univerzalan karakter - pokušaj da se otklone društvene nepravde koje su deo svakodnevice svih mladih recipijenata, bez obzira na to u kom vremenu žive.

\section{Zaključna razmatranja}

Na ovom mestu želeli bismo da se osvrnemo i na položaj Sonje Sever u sinhronoj i dijahronoj perspektivi, odnosno na svojevrsni paradoks - priznatosti i značaja u datom (socrealističkom) vreme$\mathrm{nu}, \mathrm{s}$ jedne strane, i manjak šireg osvrta na njeno delovanje u sklopu južnoslovenske socrealističke stilske formacije $u$ književnosti za decu i omladinu, s druge. O relevantnosti autorke za period socijalističke Jugoslavije indikativno je navesti stanovište Branka Ćopića, jednog od retkih socrealističkih pisaca sa naših prostora kojem je u širem kontekstu priznat umetnički kredibilitet:

U Hrvatskoj mladi pisci pokazuju veoma malo aktivnosti na polju dječje literature, iako na toj liniji, naročito u prozi, imaju utrven put radovima Nazora, Ivane Brlić Mažuranić, Mate Lovrka, Pavičić i drugih. Od mladih jedino nešto veću aktivnosti pokazuje Danko Oblak, dok su još uvijek najviše čitani i najviše od sebe daju stariji pisci za decu Mato Lovrak, Josip Pavičić, Sonja

Sever i drugi (1950, 23).

Kada pak govorimo o odsutnosti autorke iz savremenog doba, možemo ukazati na potencijalne razloge njene dvostruke marginalizacije. Treba imati u vidu da njena pripadnost socrealističkoj stilskoj formaciji u izvesnom smislu a priori donosi svojevrsno osporavanje umetničkih kvaliteta i literarnu stigmatizaciju. Međutim:

Ignorisati čitav period književnog stvaralaštva, koji je bio dominantan na prostorima slovenskog sveta od Vladivostoka do Odre i Nise, od Baltika pa do krajnjeg juga Balkana; koji je bio nametnut ili prihvaćen od strane mnogih neslovenskih naroda na nekoliko kontinenta $\mathrm{u}$ vremenu od početka pa skoro do kraja $\mathrm{XX}$ veka, za koje vreme je postojala ogromna književna produkcija, koja se meri hiljadama naslova, mnoštvom autora - jednako je spaljivanju knjiga i brisanju jednog dela kreativnog pamćenja čovečanstva (Konstantinović 2007, 9).

Drugi razlog marginalizacije možemo tražiti u skrajnutosti književnica iz istorija književnosti na južnoslovenskim prostorima: 
Feministkinje ne razumeju marginalnost samo kao stigmatizovanu poziciju žena, već najviše kao mesto otpora, koje je suštinsko za podređene, eksploatisane i porobljene ljude. To je mesto mogućnosti otkrivanja moći žena, ali i jedne drugačije, ućutkane istorije. Takođe, to je i moguća potvrda prisustva neadekvatnih metoda naučnika, čiji dupli standardi u ocenjivanju vrednosti dela autora različitih polova osiguravaju trajnu marginalizaciju autorkama, perpetuirajući nepromenjen status ženske sfere kulture, koja ostaje izvan nacionalnog, kulturnog i obrazovnog kanona (Tomić 2014, 169).

Ne treba, ipak, izgubiti iz vida da su skromniji literarni dometi, ali i teškoće u komunikaciji sa savremenim mladim čitaocima, kojima je društveni sistem socijalističke Jugoslavije dalek i nepoznat, verovatno glavni razlozi za pozicioniranje Sonje Sever na književnu marginu. Kao što smo prikazali analizom dvaju romana za decu $\mathrm{i}$ omladinu (Majko, zašto? i Mali Kinez Kong), ideološki aspekti jesu dominante strukture, kojima su podređeni različiti umetnički postupci. Ipak, i u skučenim poetskim uzusima socrealizma, Sonja Sever je uspela da izrazi svoj kreativni potencijal, te da napiše delove koji nesumnjivo plene svojom estetskom uspelošću, što je najvidljivije u deskriptivnim slojevima teksta, kao i prevazilaženju socrealističke matrice. Delo Sonje Sever nesumnjivo otvara različita pitanje odnosa literarnog i ideološkog u književnosti za decu i omladinu, a njena važnost za datu stilsku formaciju bez zadrške iziskuje šira komparativna razmatranja, što može biti i put ka revalorizaciji i aktualizaciji interesovanja akademske zajednice za ovu autorku, ali i čitalačke publike, koja u njenom delu može pronaći vredno literarno svedočanstvo o jednom periodu i jednom pogledu na svet.

\section{Literatura}

Addison, James Thayer. 1924. „The Modern Chinese Cult of Ancestors“. The Journal of Religion Vol. 4, Number 5 Sep.: 492-503.

Alečković, Mira. 1955. „Deset godina jugoslovenske literature za decu“. Letopis Matice srpske 131 (376/4): 364-386.

Arežina, Sanja. 2013. Odnos NR Kine s Jugoslavijom i Srbijom od 1977. do 2009. godine. Doktorska disertacija. Univerzitet u Beogradu Fakultet političkih nauka.

Ćopić, Branko. 1950. „Naša dečja književnost“. Nastava jezika i književnosti u srednjoj školi 1 (1-2): 20-28. 
Draginčić, Slavko i Zdravko Zupan. 2005. Istorija jugoslovenskog stripa I. Dostupno na https://www.rastko.rs/strip/1/zupan-draginicic_1/ index_l.html

Flaker, Aleksandar. 1985. „Socijalistički realizam“. Rečnik književnih termina. Nolit: Beograd.

Gorki, Maksim. 1945. „O temama dečje književnosti“. Dajte deci literaturu. Beograd: Novo pokoljenje: 11-24.

Hrvatska enciklopedija Online. Dostupno na: https://enciklopedija.hr/

Idrizović, Muris. 1976. „Narodnooslobodilačka borba u djelima lektire“. Detinjstvo: časopis o književnosti za decu 2 (2): 35-36.

Konstantinović, Stevan. 2006. Ideologija u književnosti za decu. Novi Sad: Ljubitelji knjige.

Konstantinović, Stevan. 2007. Socrealistički roman u slovenskim književnostima. Novi Sad: Ljubitelji knjige.

Kovač, Zvonko. 2010. „Dvojna pripadnost (višepripadnost) opusa. O kulturi razgovora (metodologiji pisanja) o pripadnosti pisaca“. U Desničini susreti 2005-2008, urednici Drago Roksandić i Ivana Cvijović Javorina, 130-142. Zagreb: Plejada: Filozofski fakultet.

Kovač, Zvonko. 2016. Interkulturne studije i ogledi: međuknjiževna čitanja, mentorstva. Zagreb: Filozofski fakultet Sveučilišta u Zagrebu. http://dx.doi.org/10.17234/9789531757560

Lukacs, Georg. 1990. Teorija romana: jedan filozofskohistorijski pokušaj o formama velike epske literature. Sarajevo: Veselin Masleša: Svjetlost.

Majhut, Berislav i Sanja Lovrić Kralj. 2016. „Slika djeteta u dječjoj književnost pedesetih godina 20. stoljeća u socijalističkoj Jugoslaviji : dijete-stanovnik dječje republike“. Detinjstvo: časopis o književnosti za decu 42 (3): 19-30.

Majhut, Berislav i Sanja Lovrić Kralj. 2017. „Josip Pavičić i socrealistički dječji roman“. Radovi Zavoda za znanstveni i umjetnički rad u Požegi 6: 59-87. https://doi.org/10.21857/ygjwrc625y

McCallum, Robyn. 1999. Ideologies of Identity in Adolescent Fiction. New York; London: Garland.

Mihurko Poniž, Katja. 2019. „Pravljice starejših slovenskih pisateljic v literarni tradiciji in vzgojno-izobraževalnem sistemu“. Jezik in slovstvo 64 (2): 5-18. https://www.jezikinslovstvo.com/pdf. php?part $=2019|2| 7-20$

Opačić, Zorana. 2013. „Ideologija i književnost u dečjoj periodici polovine XX veka“.U Književnost za decu i njena uloga u vaspitanju i obrazovanju dece školskog uzrasta: tematski zbornik, urednik Sunčica Denić, 295308. Vranje: Učiteljski fakultet.

Opačić, Zorana. 2017. „Vidovi ideološkog diskursa u književnosti za decu i mlade“. Inovacije u nastavi XXX (2017/3): 17-128.

Pijanović, Petar. 2012. Srpski kulturni krug 1900-1914. Beograd: Institut za književnost i umetnost. 
Pirnat-Cognart, Zlata. 1980. Pregled mladinskih književnosti jugoslovanskih narodov: (1945-1968). Ljubljana: Mladinska knjiga.

Sever, Sonja. 1947. Majko, zašto?. Zagreb: Prosvjeta.

Sever, Sonja. 1948. Mali Kinez Kong. Zagreb: Prosvjeta.

Slovenska mitologija - enciklopedijski rečnik. 2001. Redaktori: Svetlana M. Tolstoj i Ljubinko Radenković. Beograd: Zepter book world.

Stevanović, Goran. 2019. „Novo 'čitanje' ilustracije kao vizuelnog teksta“. Glasnik Narodne biblioteke Srbije 18 (21): 73-83.

Tauber, Viktor Isaievič. 1945. „O ilustrovanju dečjih knjiga“. Dajte deci literaturu. Beograd: Novo pokoljenje: 39-46.

Tomić, Svetlana. 2014. „Norma, književnice i istina“. Kultura: časopis za teoriju i sociologiju kulture i kulturne politike 143: 168-186.

Uspenski, Boris Andrejevič. 1979. Poetika kompozicije. Semiotika ikone. Beograd: Nolit.

Zidanski, Urša. 2016. Ponikva v slovenski kulturni zgodovini. Diplomsko delo. Univerza v Mariboru - Filozofska fakulteta.

Zima, Dubravka. 2001. „Hrvatska dječja književnost o ratu“. Polemos IV (8): 81-122. https://hrcak.srce.hr/2835

\author{
Vanja Petrović \\ Univerza na Primorskem \\ Fakulteta za humanistične študije \\ Koper, Slovenija \\ vanjapetrovic444@gmail.com \\ Darko Ilin \\ Univerza v Novi Gorici \\ Fakulteta za humanistiko \\ Slovenija \\ darko.ilin@yandex.com
}

\title{
SOCREALISTIČNA POETIKA V ROMANIH SONJE SEVER ZA OTROKE IN MLADINO OBJAVLJENIH V SRBOHRVAŠKEM JEZIKU
}

Cilj tega članka je obravnavati Sonjo Sever v kontekstu njene pripadnosti slovenski literarni tradiciji, hkrati pa tudi skupnemu literarnemu sistemu socialistične Jugoslavije. Posebno pozornost bomo namenili različnim vidikom socrealistične poetike, ki predstavlja dominanten pripovedni diskurz v pripovednem opusu Sonje Sever za otroke in mladino v srbohrvaškem jeziku. $\mathrm{V}$ tem članku bova na podlagi romanov Mali Kinez Kong in Majko, zašto? pokazala, kako je 
socrealistična poetika vplivala na zgradbo literarnih del, oblikovanje likov in ideologiziranje svetovnega nazora. Fokus raziskave je usmerjen na načine, kako avtorica presega ozke okvire in matrice te literarne usmeritve, ki jo sooča s posebnimi zahtevami in funkcijami literature za otroke in mladino, ter s tem ustvari na marsikateri način vredna literarna dela.

Ključne besede: Sonja Sever, socrealizem, književnost za otroke in mladino, ideologija

\author{
Vanja Petrović \\ University of Primorska \\ Faculty of Humanities \\ Koper, Slovenia \\ vanjapetrovic444@gmail.com \\ Darko Ilin \\ University of Nova Gorica \\ School of Humanities \\ Slovenia \\ darko.ilin@yandex.com
}

\title{
POETICS OF SOCIALIST REALISM IN THE NOVELS FOR CHILDREN AND YOUTH BY SONJA SEVER WRITTEN IN SERBO-CROATIAN
}

The aim of this paper is to examine Sonja Sever in the context of her affiliation with Slovene literary tradition, as well as of her belonging to the common literary system of socialist Yugoslavia. Special attention is paid to the various aspects of the poetics of Socialist Realism, that represents the dominant narrative discourse in the prose works of Sonja Sever for children and youth, written in the Serbo-Croatian language. In this paper, we will show how the poetics of Socialist Realism influenced the formation of literary works, characters and the ideologized outlook on the world. The research focus is also directed to the ways in which the author succeeds in overcoming the narrow frameworks of this literary trend by confronting it to the specific demands and functions of literature for children and youth, thereby creating works that have a multifaceted artistic value.

Keywords: Sonja Sever, Socialist Realism, literature for children and youth, ideology 